\title{
KULT ŚWIĘTYCH A ZWYCIĘSTWA MILITARNE PIERWSZYCH PIASTÓW (OD X DO POCZĄTKÓW XIII W.)
}

Kult świętych i powiązany z nim kult relikwii rozwijał się w chrześcijaństwie zachodnim od IV w. i i odgrywał niezwykle ważną rolę w religijności i mentalności ludzi średniowiecza. Świętych uważano za szczególnych patronów dedykowanych im instytucji kościelnych, ale również wspólnot politycznych oraz stojących na ich czele władców². Szczególna więź istniała pomiędzy wspólnotą a tymi świętymi, których relikwiami opiekowała się dana społeczność. Patron, realnie obecny w świętych szczątkach, ze względu na swoje zasługi za życia stawał się najskuteczniejszym pośrednikiem między bliskimi mu ludźmi a Bogiem. Dzięki skutecznej intercesji pomagał zapewnić zbawienie wieczne, ale również wyjednać pomyślność w doczesnym życiu³ . Do pomocy i opieki świętych patronów odwoływano się szczególnie w momentach kryzysu, m.in. podczas działań wojennych ${ }^{4}$. W historiografii polskiej nie analizowano dotychczas szczegółowo tego aspektu średniowiecznego kultu świętych. Jan

\footnotetext{
* Monika Juzepczuk, Instytut Historyczny Uniwersytetu Warszawskiego. Zainteresowania badawcze: monarchia Kapetyngów od X do XIII w., historia Polski piastowskiej, ideowe podstawy władzy monarszej w średniowieczu, kultura religijna i polityczna wczesnego oraz pełnego średniowiecza, rola i znaczenie kultu świętych i relikwii, monastycyzm średniowieczny. E-mail: monikajuzepczuk@gmail.com.

1 P. Brown, Kult świętych: narodziny i rola w chrześcijaństwie łacińskim, tłum. J. Partyka, Kraków 2007, s. 1-7; N. Hermann-Mascard, Les reliques des saints. Formation coutumière d'un droit, Paris 1975, s. 16-17.

2 P. Geary, Furta sacra. Thefts of relics in the Central Middle Ages, Princeton 1990, s. 34; P. Brown, op. cit., s. 73-88. O znaczeniu kultu świętych i relikwii jako patronów władców zob.: E. Bozóky, La politique des reliques de Constantin à Saint Louis, Paris 2006, s. 15-72; J. Pysiak, Król i Korona Cierniowa. Kult relikwii we Francji Kapetyngów, Warszawa 2012; idem, Gest władcy i wizualizacja treści ideowych kultu relikwii za panowania Ludwika Świętego, w: Wielkopolska - Polska - Europa. Studia dedykowane pamięci Alicji Karłowskiej-Kamzowej, red. J. Wiesiołowski, J. Kowalski, Poznań 2006, s. 21-22.

3 Zob. m.in.: P. Geary, op. cit., s. 34, 63-65; M. Juzepczuk, Kult relikwii św. Waldeberta w opactwie w Luxeuil $w X$ wieku $w$ świetle „Miracula sanctorum Waldeberti et Eustasii”, „Średniowiecze polskie i powszechne”, 12/2016, t. 8, s. 13-45; M. R. Pauk, Święci patroni a średniowieczne wspólnoty polityczne w Europie Środkowej, w: Sacrum. Obraz i funkcja w społeczeństwie średniowiecznym, red. A. Pieniądz-Skrzypczak, J. Pysiak, Warszawa 2005, s. 237-260; J. Pysiak, Teatralizacja kultu relikwii w średniowieczu, w: Obrzęd, teatr, ceremoniał w dawnych kulturach, red. J. Olko, Warszawa 2008, s. 31-33; M. Starnawska, Relikwie jako fundament ideowy wspólnoty w tradycji polskich przekazów średniowiecznych (Św. św. Wojciech, Florian, Stanisław, Drzewo Krzyża Św. na Łyścu), w: Sacrum. Obraz i funkcja w społeczeństwie średniowiecznym, s. 261-279; eadem, Świętych życie po życiu. Relikwie w kulturze religijnej na ziemiach polskich $w$ średniowieczu, Warszawa 2008, s. 600-603.

4 P. Geary, op. cit., s. 32, 129-134; J. Banaszkiewicz, Wtócznia i choragiew. O rycie otwierania bitwy w związku z cudem kampanii nakielskiej Bolesława Krzywoustego (Kadtubek III, 14), „Kwartalnik Historyczny”, 94/1988, z. 4, s. 6-7; M. R. Pauk, op. cit., s. 255-259; P.-A. Sigal, L’homme et le miracle dans la France médiévale (XIe-XIIe siècle), Paris 1985, s. 271-273.
} 
Malicki w swoim artykule skupia się na recepcji kultu świętych rycerskich i jego znaczeniu dla wspólnoty5. Maria Starnawska poruszyła w swoich pracach to zagadnienie, skupiając się jednak głównie na roli samych relikwii ${ }^{6}$. Niniejszy artykuł poszerza pole badawcze, kładąc nacisk na znaczenie różnych aspektów kultu świętych, a szczególnie dokonywanych przez nich cudów, w działaniach militarnych za czasów pierwszych Piastów, kiedy chrześcijaństwo w Polsce nie było jeszcze ugruntowane. Będzie to stanowić przyczynek do prześledzenia procesu recepcji kultu świętych na ziemiach polskich i porównania go z wzorcami ukształtowanymi na zachodzie Europy.

Pierwszy przekaz o cudownej pomocy udzielonej władcy piastowskiemu przez świętego pochodzi z Vita sancti Oudalrici. Tekst ten został spisany w latach 973-992 przez Gerharda, proboszcza katedry w Augsburgu i miał być świadectwem świętości Udalryka, biskupa tego miasta, spowiednika Ottona I7. Do tekstu Vita dołączono opisy trzydziestu cudów pośmiertnych Udalryka. Większość z nich opowiada o wydarzeniach związanych z Augsburgiem, głównie o uzdrowieniach. Nieco inny charakter mają rozdziały 2I i 22. Opowiadają one o cudach dokonanych z dala od miejsca spoczynku relikwii, których doświadczyli syn księcia słowiańskiego Bolesława i książę Mieszko. Ten ostatni zraniony został zatrutą strzałą w ramię, bliski śmierci, zwrócił się z prośbą o pomoc do św. Udalryka i obiecał ofiarować mu wotum w postaci srebrnego ramienia. Święty wysłuchał prośby księcia, który natychmiast nakazał sporządzenie niezwykle bogatego wotum ${ }^{8}$. Przekaz ten jest współczesny opisywanym wydarzeniom i stanowi pierwsze świadectwo recepcji kultu relikwii na ziemiach polskich9. Przybycie do Augsburga posłów z odległych krajów z tak hojnymi darami nie mogło ujść uwadze mieszkańców miasta, a otrzymane wota zawsze eksponowano, aby świadczyły o mocy i skuteczności świętego, przyciągając nowych pielgrzymów ${ }^{10}$. Możliwe więc, że rzeczywiście w tym okresie wysłannicy z ziem polskich złożyli św. Udalrykowi wotum. Hagiograf pragnący przede wszystkim głosić chwałę świętego nie poinformował czytelników o okolicznościach zranienia Mieszka. Prawdopodobnie jednak można łączyć

\footnotetext{
5 J. Malicki, Treści polityczne i ideowe kultu świętych rycerskich w Polsce wcześniejszego średniowiecza. Próba oceny, w: Kultura średniowieczna i staropolska. Studia ofiarowane Aleksandrowi Gieysztorowi w pięćdziesięciolecie pracy naukowej, red. D. Gawinowa et al., Warszawa 1991, s. 387-394; M. Starnawska, Świętych życie po życiu, s. 569-574.

6 M. Starnawska, Świętych życie po życiu, s. 569-574.

7 T. Dunin-Wąsowicz, Kulty świętych w Polsce w Xw., w: Polska w świecie. Szkice z dziejów kultury polskiej, red. J. Dowiat et al., Warszawa 1972, s. 62-64; J. Strzelczyk, Wandalowie i ich afrykańskie państwo, Warszawa 1992, s. 313-314.

8 „Alio quoque tempore quidam dux Wandalorum, Misico nomine, cum sagitta toxicata in brachium vulneratus est. Qui cum sentiret sese veneno nocivo esse percussum, et sibi inminere mortis interitum eadem hora putaret, cum magna fide et constantia votum vovit, ut brachium argenteum cum manu quam cicius potuisset ad sanctum Oudalricum mittere non differret. Qui statim post votum revelatus a periculo, ad domum suam rediit, et brachium secundum suum votum componere praecepit”. Gerhardi vita Sancti Oudalrici episcopi, wyd. G. Waitz, ,Monumenta Germaniae Historica“ Scriptores in folio (dalej: MGH SS) t. 4, Hannoverae 1841, s. 423. Określenie „dux Wandalorum" zostało użyte przez autora wskutek przeniesienia nazwy plemienia Wandalów na ludy sąsiadujące od wschodu z Cesarstwem. Karolińscy rocznikarze nazywali tak Awarów, a później również Słowian Połabskich. Wandalami nazywał Słowian Adam z Bremy w XI w. i Gerwazy z Tilbury na przełomie XII i XIII w. Polscy dziejopisarze, najprawdopodobniej za przykładem zachodnich historiografów, także zaczęli nazywać mieszkańców ziem polskich Wandalami (jako pierwszy nawiązał do tego Wincenty Kadłubek w opowieści o Wandzie, ale ten wątek został rozwinięty w historiografii XIV-wiecznej), zob. J. Strzelczyk, op. cit., s. 309-335.

9 M. Starnawska, Świętych życie po życiu, s. 336-337, 350-351.

10 P.-A. Sigal, op. cit., s. 86-107, 184-185.
} 
je z prowadzonymi przez władcę działaniami militarnymi. Uzdrowienie Mieszka nie było jednak tylko odpowiedzią na pobożną prośbę nieznanego bliżej wiernego. Mieszko stał na czele wspólnoty politycznej, która mogłaby ucierpieć w razie przedwczesnej śmierci władcy. Beneficjentem cudu nie był więc tylko pojedynczy wierny, lecz cała wspólnota. Ponadto uratowanie księcia od pewnej śmierci potwierdzało, że jest on godzien sprawowania swojej funkcji. Święty nie udzieliłby mu takiej łaski, gdyby nie uważał, że Mieszko dobrze spełnia obowiązki władcy, powierzone mu przecież przez Boga. Cud uzdrowienia ze śmiertelnie groźnej rany odniesionej w walce z wrogiem mógłby służyć legitymizacji władzy Mieszka. Najprawdopodobniej jednak tak się nie stało. Nie wiadomo nic o ewentualnym rozpowszechnieniu się w państwie Mieszka kultu św. Udalryka. Teresa Dunin-Wąsowicz przypuszcza, że było to spowodowane zmianą polityki zagranicznej Mieszka. Zerwał on związki z bawarską arystokracją, która promowała kult biskupa Augsburga na rzecz ściślejszego sojuszu z dworem ottońskim ${ }^{\text {II }}$. Bawarski święty nie mógł więc w tych okolicznościach patronować Mieszkowi.

Pierwsze przekazy o bezpośredniej interwencji świętych w militarne działania władców piastowskich znajdują się w dziełach Brunona z Kwerfurtu: Żywocie Pięciu Braci Męczenników i liście do króla Henryka. Żywot Pięciu Braci ${ }^{\mathrm{I2}}$ opisuje życie, śmierć męczeńską i cuda pośmiertne pięciu eremitów: Benedykta i Jana, którzy przybyli do Polski z Pereum, oraz Mateusza i Izaaka, eremitów miejscowego pochodzenia, a także ich kucharza, Krystyna. Osiedli oni w eremie na terenie państwa Bolesława Chrobrego i zostali zamordowani w I003 r. Zaraz po ich śmierci w klasztorze, w którym zostali pochowani, zaczęły dziać się liczne cuda. Jeden z nich świadczyć miał o opiece, jaką święci męczennicy otaczali kraj Bolesława Chrobrego podczas najazdu króla Henryka II: „Cum illam uillam regis Saxonum exercitus magnus et ualidus ascenderet, et quin tota prouincia periclitaretur, nemo fere dubitaret, in medio noctis, qui longa luce per totam curtem aspexit, et integra hora manens stetit, uidetur super illam ecclesiam quasi circulus ingens et splendidus"'13.

Następnie autor podaje interpretację tego cudu: „ut ex priore signo eorum protectione protectam terram homines intelligerent, quam sine effectu cogitatę perdicionis illesam reliquit exercitus regis"'I4. Święci męczennicy, zdaniem Brunona, obronili kraj, czego widomym

\footnotetext{
11 T. Dunin-Wąsowicz, Kulty świętych w Polsce $w$ Xw., s. 67.

12 Literatura dotycząca Pięciu Braci Męczenników jest w polskiej historiografii bardzo obszerna, zob. m.in.: M. Derwich, Kilka uwag w sprawie Pięciu Braci Męczenników, w: Cracovia-Polonia-Europa. Studia z dziejów średniowiecza ofiarowane Jerzemu Wyrozumskiemu w sześćdziesiąta piąta rocznicę urodzin i czterdziestolecie pracy naukowej, red. K. Baczkowski et al., Kraków 1995, s. 181-188; T. Dunin-Wąsowicz, Najstarsi polscy święci: Izaak, Mateusz i Krystyn, w: Kościót, kultura, społeczeństwo. Studia z dziejów średniowiecza i czasów nowożytnych, red. S. Bylina, Warszawa 2000, s. 35-47; K. Górska-Gołaska, Kult Pięciu Braci Męczenników w Kazimierzu Biskupim, „Roczniki Historyczne”, 61/1995, s. 111-120; J. Karwasińska, Świadek czasów Chrobrego - Brunon z Kwerfurtu, w: Polska w świecie. Szkice z dziejów kultury polskiej, red. J. Dowiat et al., Warszawa 1972, s. 91-107; B. Kürbis, Purpurae passionis aureus finis. Bruno z Kwerfurtu i Pięciu Braci Eremitów, w: eadem, Na progach historii, t. 2: O świadectwach do dziejów kultury Polski średniowiecznej, Poznań 2001, s. 163-180; R. Michałowski, Translacja Pięciu Braci Polskich do Gniezna. Przyczynek do dziejów kultu relikwii w Polsce wczesnośredniowiecznej, w: Peregrinationes. Pielgrzymki w kulturze dawnej Europy, red. H. Manikowska, H. Zaremska, Warszawa 1995, s. 173-184; S. Trawkowski, Bolesław Chrobry i eremici, w: Prusy-Polska-Europa. Studia z dziejów średniowiecza i czasów wczesnonowożytnych, red. A. Radzimiński, J. Tandecki, Toruń 1999, s. 163-171.

13 Vita quinque fratrum eremitarum [seu] vita uel passio Benedictii et Iohannis sociorumque suorum auctore Brunone Querfurtensi, wyd. J. Karwasińska, „Monumenta Poloniae Historica”, series nova (dalej: MPH, s. n.), t. 4, cz. 3, Warszawa 1973, s. 69.

14 Ibidem, s. 69.
} 
znakiem był cudowny blask, otaczający wioskę w pobliżu klasztoru, gdzie spoczywały ich relikwie. Ten sam autor pisze jeszcze obszerniej o nadprzyrodzonej opiece patronów nad państwem Chrobrego podczas najazdu króla Henryka w liście skierowanym do tego władcy. Hagiograf potępia w nim króla za prowadzenie wojny przeciwko Bolesławowi Chrobremu W sojuszu z poganami: „Nonne cum paganis et christianis hanc terram in uiribus regni rex intrauit? Quid tum? Sanctus Petrus huius tributarium se asserit, et sanctus martyr Adalbertus, nonne protexerunt? Si adiuare nollent nunquam sancti qui sanguinem fuderunt, et sub diuino terrore multa miracula faciunt, quinque martyres occisi in terra sua requiescerent"

Jako obrońcy Polski występują tutaj obok Pięciu Braci św. Piotr oraz św. Wojciech ${ }^{16}$. Bruno wspomina także o świętym Maurycym: „Quae conuentio Christi ad Belial? quę comparatio luci ad tenebris? quo modo conueniunt Zuarasiz diabolus et dux sanctorum, uester et noster Mauritius?"', jednak nawiązuje raczej do jego patronatu nad władcami niemieckimi, chcąc zaznaczyć niestosowność sojuszu króla z poganami. Nie łączy niepowodzeń Henryka z ewentualną protekcją tego świętego, jaką mógłby się cieszyć Bolesław Chrobry po otrzymaniu od Ottona III kopii świętej włóczni. Zwrot „uester et noster Mauritius” mógł raczej zostać użyty, aby zaznaczyć jedność króla i Bolesława w wierze i przeciwstawić ją pogaństwu $^{18}$. Roman Michałowski podkreśla, że list Brunona był pisany na dworze Bolesława Chrobrego i stanowił wyraz poglądów nie tylko samego autora, ale także polskiego władcy i jego otoczenia ${ }^{19}$. Przecież to sam książę uważał się za trybutariusza św. Piotra (,tributarium se asserit”), prawdopodobnie w następstwie oddania kraju pod opiekę tego świętego przez Mieszka I. O tym fakcie informuje słynny regest dokumentu zwany $D a-$ gome iudex ${ }^{20}$. Oznaczałoby to, że już Mieszko, oddając kraj pod protekcję świętego, liczył na jego pomoc, także w zmaganiach militarnych, a Bolesław rzeczywiście w nią wierzył ${ }^{21}$. Ponadto Bruno uważał św. Piotra za patrona swojej działalności misyjnej, którą wspierał Chrobry ${ }^{22}$. Bolesław mógłby więc liczyć także na poparcie Księcia Apostołów ze względu na zaangażowanie w ewangelizację pogan. Obok św. Piotra pojawia się w narracji Brunona św. Wojciech. Jego postać również była związana z prowadzeniem misji do pogan, podobnie jak Pięciu Braci, którzy przecież porzucili erem, aby prowadzić ewangelizację. Bruno podkreśla, że już sama obecność ciał tych męczenników na terenie państwa Chrobrego

\footnotetext{
15 Epistola Brunonis ad Henricum regem - List Brunona do króla Henryka, wyd. H. Karwasińska, MPH, s. n., t. 4, cz. 3, Warszawa 1973, s. 103.

16 Literatura dotycząca kultu św. Wojciecha w Polsce jest bardzo obszerna, zob. m.in. G. Labuda, Święty Wojciech. Biskup-męczennik, patron Polski, Czech i Węgier, Wrocław 2004; Kanonizacja św. Wojciecha i dziedzictwo jego kultu, red. J. Strzelczyk, Cz. Pest, W. Polak, Lublin 2001; Święty Wojciech w Polskiej tradycji historiograficznej. Antologia tekstów, wyboru dokonał i oprac. G. Labuda, Warszawa 1997.

17 Epistola Brunonis, s. 101.

18 O kulcie św. Maurycego na ziemiach polskich zob. T. Dunin-Wąsowicz, Rzymskie kulty świętych w Polsce wczesnośredniowiecznej: kult św. Maurycego i Legionu Tebańskiego, „Roczniki Teologiczno-Kanoniczne”, 20/1973, z. 4, s. 25-34.

19 R. Michałowski, Zjazd gnieźnieński. Religijne przesłanki powstania arcybiskupstwa gnieźnieńskiego, Wrocław 2005, s. 229-241.

20 O regeście dokumentu tzw. Dagome iudex zob. B. Kürbis, Dagome iudex. Studium krytyczne, w: Początki państwa polskiego. Księga Tysiąclecia, t. 2: Spoteczeństwo i kultura, red. K. Tymieniecki, G. Labuda, T. Łowmiański, Poznań 1962, s. 362-423.

21 R. Michałowski, Princeps fundator. Studium z dziejów kultury politycznej w Polsce X-XIII wieku, Warszawa 1989, s. 97-100.

22 Ibidem, s. 234.
} 
świadczy o udzielanej mu przez nich pomocy i o tym, że aprobują oni jego działania militarne. Gdyby go nie popierali, ich ciała spoczywałyby w innym miejscu. Święty, realnie obecny w relikwiach, sam decydował o miejscu ich spoczynku i w każdej chwili mógł za pomocą cudownych wydarzeń doprowadzić do translacji swoich szczątków ${ }^{23}$. Skoro więc święci wybrali kraj podległy Chrobremu na miejsce spoczynku swoich ciał, to książę musiał zasłużyć na ich przychylność, dobrze wypełniając powierzone mu przez Boga obowiązki i wspierając działalność misyjną. Bruno, pisząc o opiece świętych nad krajem Bolesława, stawia pytania retoryczne tak, jakby wyrażane przez niego opinie były oczywiste nie tylko dla niego samego, ale również dla odbiorcy tekstu, niezależnie od tego, czy miał nim być król Henryk, czy też, jak przypuszcza Roman Michałowski, list ten stanowił jedynie rodzaj ideowego testamentu Brunona ${ }^{24}$. Jakkolwiek zinterpretuje się przeznaczenie tego dzieła, faktem jest, że dla Brunona oraz najprawdopodobniej dla Bolesława Chrobrego i jego otoczenia opieka świętych patronów podczas zmagań militarnych była czymś oczywistym, zwłaszcza w obliczu sojuszu cesarza z poganami.

Przekonanie to wpisuje się w szerszy kontekst rozumienia przez Brunona misji chrystianizacyjnej. Wszyscy wymienieni przez niego święci patroni byli związani z chrystianizacją pogan: św. Wojciech poniósł śmierć męczeńską podczas misji do Prusów, powołaniem i największym pragnieniem Pięciu Braci było podjęcie misji, a św. Piotra Bruno uznawał za patrona własnej działalności misyjnej. Zasługom tych świętych hagiograf przypisywał powodzenie prowadzonej przez niego samego chrystianizacji pogan ${ }^{25}$. Zatem święci, interweniując w działania zbrojne po stronie Bolesława, nie tylko stawali w obronie chrześcijańskiego władcy, potwierdzając, że cieszy się on opieką Niebios i legitymizując jego władzę, ale również dbali o zapewnienie korzystnych warunków do prowadzenia tak bliskiej im działalności misyjnej. Motyw ten będzie obecny także w późniejszych przekazach o opiece świętych nad władcami piastowskimi w czasie wojen.

Kronika Galla Anonima opowiada o dwóch takich przypadkach. Pierwszy z nich to niezwykle ciekawy cud św. Wojciecha dokonany w noc poprzedzającą konsekrację odbudowanej przez Władysława Hermana katedry gnieźnieńskiej ${ }^{26}$. Według kronikarza tej nocy pogańscy Pomorzanie, z którymi polski książę toczył już wcześniej walkę, chcieli opanować podstępem pewien gród: „Sed ille, qui semper vigilat, nunquam dormitabit, oppidanos dormientes sui militis Adalberti vigilantia custodivit et paganos in insidiis christianorum vigilantes armorum terror spiritualium agitavit. Apparuit namque quidam super album equum Pomoranis armatus, qui gladio eius extracto territabat, eosque per gradus et solium castri precipites agitabat. Sicque procul dubio castellani, clamoribus paganorum et tumultibus excitati, defensione gloriosi martiris Adalberti ab imminenti sunt mortis periculo liberati" ${ }^{27}$.

Takie przedstawienie św. Wojciecha jest dość nietypowe, ponieważ zazwyczaj działania świętych ukazujących się w wizjach i sprawiających cuda są transpozycją ich dokonań za

\footnotetext{
${ }^{23}$ Zob. P. Geary, op. cit., s. 33, 61-62, 120-125.

24 R. Michałowski, Zjazd gnieźnieński, s. 231.

25 Ibidem, s. 239; idem, Chrystianizacja monarchii piastowskiej, w: Animarum cultura. Studia nad kultura religijna na ziemiach polskich w średniowieczu, t. 1: Struktury kościelno-publiczne, Warszawa 2008, s. 37, 44.

26 „Et quoniam ecclesie mencio Gnesnensis in hoc fieri forte contigerit, non est dignum preterire miraculum, quod in vigilia dedicacionis preciosus martir Adalbertus et paganis et christianis ostenderit", Galli Anonymi cronica et gesta ducum sive principium Polonorum, wyd. K. Maleczyński, MPH, s. n., t. 2, Kraków 1952, II 6, s. 73.

27 Ibidem, II 6, s. 73.
} 
życia ${ }^{28}$, zaś w tym przypadku święty biskup i skromny męczennik ukazał się jako zbrojny mąż na koniu ${ }^{29}$. W kronice Galla postać św. Wojciecha jeszcze raz pojawia się w kontekście militarnym. Gnieźnieński hufiec, biorący udział w jednej z opisywanych bitew był poświęcony właśnie Wojciechowi, a więc wierzono w jego skuteczną intercesję i opiekę podczas walki $^{30}$. Cudowna pomoc udzielona mieszkańcom grodu zagrożonego przez Pomorzan została jednak opisana w szczególnym kontekście. Stanowiła ona odpowiedź na dar złożony świętemu przez księcia Władysława Hermana, jakim była odbudowana i konsekrowana na nowo katedra gnieźnieńska. Jak zauważa Roman Michałowski, św. Wojciech daje w ten sposób dowód przyjęcia daru Władysława i wzięcia w opiekę całego jego państwa ${ }^{31}$. Opisany cud potwierdza też autentyczność relikwii świętego przechowywanych w Gnieźnie oraz fakt, że św. Wojciech jest nadal patronem Polski ${ }^{32}$. Jak podkreśla Maria Starnawska, takie odnowienie więzi z patronem było szczególnie ważne dla wspólnoty politycznej. Fundamentem ideowym jej istnienia były właśnie relikwie św. Wojciecha, które zostały wywiezione przez czeskiego księcia Brzetysława i biskupa praskiego Sewera podczas najazdu na Polskę w I038 r.33. Duchowieństwo gnieźnieńskie w XII w. utrzymywało, że nadal posiada święte szczątki męczennika, a roczniki pod datą II27 donoszą o dokonaniu inwencji głowy Wojciecha w Gnieźnie ${ }^{34}$. W narracji Galla św. Wojciech włącza się w walkę zbrojną prowadzoną przez księcia z pogańskimi Pomorzanami. W czasach powstawania kroniki, kiedy problem Pomorza absorbował Bolesława Krzywoustego i całą elitę jego państwa, łączono dzieło chrystianizacji tego obszaru z wcześniejszymi zasługami misyjnymi św. Wojciecha. Wprost piszą o tym autorzy żywotów chrystianizatora Pomorza, św. Ottona z Bambergu. Niektóre cuda Ottona przypisywane są wstawiennictwu św. Wojciecha ${ }^{35}$. Vita Prieflingensis przedstawia misję bamberskiego biskupa jako kontynuację dzieła Wojciecha, który według tego źródła zginął wśród Pomorzan ${ }^{36}$. Swoim poświęceniem Wojciech miał zapewnić powodzenie przyszłej misji. Dzieło męczennika, dzięki jego zasługom, wypełnił ostatecznie

28 P.-A. Sigal, op. cit., s. 35-36.

29 Jak zauważa R. M. Pauk, w historiografii czeskiej podobną zmianę dostrzec można w wizerunku św. Wacława, początkowo przedstawianego jako miłującego pokój męczennika. W 1126 r. święty miał przyczynić się do zwycięstwa księcia Sobiesława nad Lotarem III pod Chlumcem, ukazując się pod postacią rycerza na białym koniu niosącego włócznię. Zob. M. R. Pauk, op. cit., s. 256-257; J. Banaszkiewicz, op. cit., s. 7; J. Malicki, op. cit., s. 392; M. Starnawska, Świętych życie po życiu, s. 570.

30 „Gnesnensis etiam acies, patrono Poloniae dedicata”, Galli Anonymi cronica, III 23, s. 151; zob. J. Banaszkiewicz, op. cit., s. 7; M. Starnawska, Świętych życie po życiu, s. 570.

31 R. Michałowski, Princeps fundator, s. 185-186.

32 M. Starnawska, Świętych życie po życiu, s. 566-567.

33 Ibidem, s. 264-265, 566-567.

34 Canonici wissegradensis continuatio Cosmae, wyd. H. G. Pertz, MGH SS, t. 9, Hannoverae 1851, s. 133; Rocznik Małopolski, wyd. A. Bielowski, MPH, t. 3, Lwów 1878, s. 152-153; Rocznik Traski, wyd. A. Bielowski, MPH, t. 2, Lwów 1872, s. 832; Rocznik Krakowski, wyd. A. Bielowski, w: Rocznik Traski, MPH, t. 2, Lwów 1872, s. 832; Rocznik Sędziwoja, wyd. A. Bielowski, MPH, t. 2, Lwów 1872, s.875; Ioannis Dlugossi Annales seu Cronicae incliti Regni Poloniae, red. I Dąbrowski, W. Semkowicz-Zaręba et. al., Warszawa 1964, I 4, s. 307; M. Starnawska, Świętych życie po życiu, s. 188-189, 280-282, W. Szołdrski, Spór polsko-czeski o relikwie św. Wojciecha, „Ateneum Kapłańskie", 42/1950, t. 52, s. 235-265.

35 R. Michałowski, Chrystianizacja monarchii, s. 41; S. Rosik, Conversio gentis Pomeranorum. Studium świadectwa o wydarzeniu (XII wiek), Wrocław 2010, s. 41-43, 307-311; Herbordi Dialogus de vita sancti Ottonis episcopi Babenbergensis, wyd. J. Wikarjak, K. Liman, MPH, s. n., t. 7, cz. 3, Warszawa 1974, III 26, s. 188-189

36 R. Michałowski, Chrystianizacja monarchii, s. 42; S. Ottonis episcopi Babenbergensis Vita Prieflingensis, wyd. J. Wikarjak, K. Liman, MPH, s. n., t. 7, cz. 1, Warszawa 1966, II 13, s. 44. 
św. Otto ${ }^{37}$. Tak najprawdopodobniej rozumiał swoją rolę sam biskup bamberski, który poznał dobrze kult św. Wojciecha w czasie pobytu na polskim dworze ${ }^{38}$. Nowo powstające kościoły na Pomorzu Otto dedykował właśnie św. Wojciechowi, który stawał się patronem ewangelizacji Pomorza ${ }^{39}$. W ten sam sposób sto lat wcześniej Bruno z Kwerfurtu postrzegał rolę św. Wojciecha i Pięciu Braci Męczenników we własnej działalności misyjnej ${ }^{\circ}$.

Kolejny opis udziału świętych patronów w zwycięstwie militarnym władcy piastowskiego dotyczy oblężenia Nakła przez wojska Bolesława Krzywoustego ${ }^{41}$. Podczas zawieszenia broni Pomorzanie znienacka zaatakowali niespodziewających się niczego Polaków, którzy właśnie wychodzili z uroczystości mszalnych. Był to dzień św. Wawrzyńca, czyli ı sierpnia. Bolesławowi udało się zebrać rozproszonych rycerzy i pokonać Pomorzan, dzięki czemu poddało się Nakło. Gall przypisuje całą zasługę zwycięstwa wstawiennictwu św. Wawrzyńca. Podkreśla, że Bóg udzielił Bolesławowi łaski dzięki prośbom patrona dnia. Wzmiankę o tym kronikarz wkłada w usta samego Bolesława, przemawiającego do rycerzy: „Hodie Deo favente, sanctoque Laurencio deprecante, Pomoranorum ydolatria ac militaris superbia vestris ensibus conteretur”ł2. Pisze też: „Testor Deum ope cuius sanctumque Laurentium, prece huius facta fuerit ista cedes"43. Jednak bohaterowie opisanej sceny nie kierują wprost modlitw do świętego. Odprawiono oczywiście, tak jak należało, uroczystą mszę ku jego czci, ale miało to miejsce tuż przed atakiem Pomorzan ${ }^{44}$. W tekście pojawiają się dwa bezpośrednie zwroty skierowane do świętego, ale są to wtrącenia autora, który nie wkłada ich w usta konkretnych osób ${ }^{45}$.

O bitwie wygranej dzięki wstawiennictwu św. Wawrzyńca pisał w XI w. Thietmar. Według niego w trakcie bitwy nad rzeką Lech w 955 r. Otto I zwrócił się do tego świętego, obiecując mu w zamian za pomoc założenie dedykowanego mu biskupstwa w Merseburgu. Dzięki wstawiennictwu św. Wawrzyńca Otto odniósł zwycięstwo i spełnił swój ślub ${ }^{46}$. W dalszej narracji Thietmara, biskupa Merseburga, epizod ten ma ogromne znaczenie, gdyż autor łączy powodzenie władców niemieckich z ich stosunkiem do fundacji Ottona I. Jego syn Otto II ponosił porażki, także na polu militarnym, ponieważ zlikwidował biskupstwo merseburskie. Tak samo interpretuje niepowodzenia Ottona II Bruno z Kwerfurtu w $\dot{Z} y$ wocie św. Wojciecha ${ }^{47}$. Łaskę św. Wawrzyńca odzyskał dopiero Henryk II, który odnowił

\footnotetext{
37 Ibidem, s. 42.

38 Ibidem, s. 42-43.

39 Ibidem, s. 42-43; S. Rosik, Conversio gentis, s. 307-311.

40 R. Michałowski, Zjazd gnieźnieński, s. 239, 44, 37.

41 Galli Anonymi cronica et gesta ducum sive principium Polonorum, wyd. K. Maleczyński, MPH, s. n., t. 2, Kraków 1952, III 1, s. 126-129.

42 Galli Anonymi cronica, III 1, s. 128.

43 Ibidem, III 1, s. 129.

44 „Gloriosus Deus in sanctis suis; venerabilis enim dies sancti Laurentij martiris existebat et in illa hora christianorum concio de missarum sollempnis exiebat et ecce subito barbarorum exercitus ibi comminus imminebat", ibidem, III, 1, s. 127.

45 „Martir Laurenti, populo succurre merenti”; ibidem; „Martir Laurenti, populo vim tolle furenti”, ibidem, III 1, S. 128.

46 Kronika Thietmara, tłum. wstęp i kom. M.Z. Jedlicki, Poznań 1953, II 10, s. 52-55.

47 Sancti Adalberti Pragensis episcopi et martyris vita altera auctore Brunone Querfurtensi, wyd. J. Karwasińska, MPH, s. n., t. 4, cz. 2, s. 7-10, 13-15.
} 
biskupstwo ${ }^{48}$. Interwencja św. Wawrzyńca na polu bitwy nad Lechem została jednak przedstawiona przez Thietmara inaczej niż zwycięstwo pod Nakłem przez Galla Anonima. W obu przypadkach władcy chrześcijańscy walczyli z poganami. Obie bitwy miały miejsce w dzień św. Wawrzyńca, jednak dla Galla był to element decydujący o przypisaniu zwycięstwa temu właśnie świętemu. U Thietmara najważniejsza jest osobista prośba władcy i obietnica ufundowania biskupstwa. Idea fundacji dziękczynnej nie była obca Gallowi, który napisał w skrócie księgi trzeciej: „In hiis ergo collaudemus Deum et Laurencium, I Die cuius sacrosancto factum est hoc prelium, I Inde sibi fiat ibi dignum edificium"49. Jednak nie wiadomo nic o tym, aby Bolesław Krzywousty w taki sposób dziękował świętemu za pomoc. Kronika Galla wyrażała najprawdopodobniej nie tylko jego osobiste poglądy, ale tworzyła oficjalną ideologię władzy księcia, którą rozumiał zarówno on sam, jak i elita jego państwa, żywo zaangażowana w tworzenie dzieła. Zwycięstwo pod Nakłem mogło zostać odniesione bez żadnej interwencji sił nadprzyrodzonych, nikt nawet o nią nie prosił. Mimo to postrzegano je jako wynik wstawiennictwa świętego męczennika, któremu poświęcony był dzień bitwy. To właśnie interpretacja danego wydarzenia przez wiernych była najważniejsza w uznaniu pewnych zjawisk za cudowne ${ }^{50}$. Udzielenie księciu pomocy w krytycznej sytuacji świadczyło o tym, że cieszył się on aprobatą św. Wawrzyńca, który uznawał prowadzoną przez niego walkę z poganami za słuszną. Ta interwencja świętego, tak jak poprzednie, miała związek z popieraniem przez Piastów działalności misyjnej, wiążącej się przecież z walką zbrojną. Ponadto święty, pomagając Bolesławowi, potwierdzał, że uważa go za godnego sprawowania władzy. Szczególnie ten ostatni aspekt był niezwykle ważny dla księcia w momencie powstawania kroniki, kiedy jego władza zachwiała się po śmierci Zbigniewa.

Temu samemu starciu pod Nakłem poświęcony jest fragment dzieła Wincentego Kadłubka, spisanego niemal sto lat później. Kronikarz ten także nawiązuje do pomocy udzielonej wojskom księcia przez św. Wawrzyńca i podkreśla, że bitwa miała miejsce w dzień jego święta, a Bolesław w swojej mowie zaznaczał, że „,hodierni gloria martiris omne illud colliquescit" ${ }^{\prime 1}$. Jednak to nie św. Wawrzyniec jest uważany za głównego sprawcę zwycięstwa wojsk książęcych: „Surgunt castra contra Maritimam et diuinam agi causam non humanam primipilarius antecurrens predocuit. Est enim beati Viti Crusuicie basilica, in cuius pinnaculo quidam inestimabilis et habitus et forme uisus est adolescens, cuius inedicibilis, ut aiunt, splendor, non modo urbem, set urbis quoque proastia illustrabat. Hic eo desiliens cum aureo pilo turmans eminus antecedit, non paucis claram numinis uirtutem cernentibus et rei tante misterium tacita ueneratione stupentibus, donec ad urbem Nakel pilum, quod gestabat, quasi vibrans disparuit. Hac ergo animatis fiducia Boleslaus obsidionibus urbem includit" $5^{2}$.

W historiografii owego młodzieńca utożsamia się najczęściej ze św. Witem ${ }^{53}$. Sam Kadłubek nie nazywa go, jednak najważniejsze jest dla niego przekonanie, że był to posłaniec

\footnotetext{
48 R. Michałowski, Princeps fundator, s. 21-25.

49 Galli Anonymi cronica, III 1, s. 125.

50 Zob. P-A. Sigal, op. cit., s. 68.

51 Magistri Vincentii dicit Kadtubek Chronica Polonorum, wyd. M. Plezia, MPH, s. n., t. 11, Kraków 1994, III 14, s. 100 .

52 Ibidem, III 14, s. 99-100.

53 Tak m.in. M. Starnawska, Świętych życie po życiu, s. 493, 571; A. Paner, Święty Wit. Męczeństwo, legenda i kult, Gdańsk 1995, s. 143-144. O kulcie św. Wita w Polsce zob. ibidem, s. 135-171; J. Soszyński, Kult św. Wita w Polsce średniowiecznej, „Przegląd Historyczny”, 75/1984, z. 3, s. 463-470. Jednak zdaniem J. Banaszkiewicza tekst źródła
} 
samego Boga. Porównuje interwencję młodzieńca z epizodem opisanym w Drugiej Księdze Machabejskiej54. Kiedy Tymoteusz, król Ammonitów, miał walczyć z Machabejczykami, w jego obozie pojawili się dwaj młodzieńcy „permiri et uultus et splendoris”弦, którzy rzucili ogień do jego obozu. Kadłubek tak to komentuje: „Quem ergo aut illum Boleslai precursorem, aut hos Machabei iuuenes estimare potes, nisi summe, nisi superexcellentis omnipotentie ministros? Adeo illi suorum cura est, ut pro illis uisibiliter nonnumquam celestibus pugnet uirtutibus. A Domino fit hoc et est mirabile in oculis nostris. [Matheus] Ego uero non tam hec miror, quod non aliena sunt iustis iustorum consortia et angelice uite hominibus etiam uisibilia non desunt angelorum umminicula" ${ }^{96}$.

Pojawienie się młodzieńca było interpretowane jako interwencja niebios na rzecz Bolesława Krzywoustego. Był on zwiastunem zwycięstwa w przyszłej bitwie, którą otwierał właśnie ów wysłannik Boga, ciskając włócznię w kierunku wroga. Taki ryt otwierania bitwy znały także społeczeństwa pogańskie ${ }^{57}$. Dodając ten epizod do opisu bitwy pod Nakłem, Kadłubek wzmacnia przedstawioną przez Galla tezę o nadprzyrodzonym charakterze odniesionego zwycięstwa. Jego zwiastunem była świetlista postać, przyrównywana do starotestamentowych Boskich wysłanników. Sukces Bolesława nie był tylko wynikiem zaimprowizowanego wstawiennictwa patrona dnia, lecz został wcześniej zaplanowany przez samego Boga, który poprzez specjalnego posłańca, skierowanego bezpośrednio do wojsk księcia, zapewniał o swoim wsparciu. Kadłubek przyrównuje tutaj Bolesława do Machabeuszy, ponieważ książę cieszył się taką samą opieką Boga jak oni i nie musiał obawiać się klęski. Kronikarz podkreśla też, że był to człowiek ,anielskiego żywota”, w pełni zasługujący na takie wyróżnienie. Dodanie tego epizodu przez Kadłubka świadczy o dużym znaczeniu tradycji o zwycięstwie pod Nakłem dla kształtowania ideologii władzy Piastów. Opowieść o boskiej pomocy w tej bitwie jest coraz bardziej rozbudowywana i coraz silniej podkreśla się w niej, jak wielką opieką boską cieszył się Bolesław, który zasłużył na specjalne wyróżnienie jeszcze przed podjęciem działań militarnych.

Przytoczone relacje o cudownym udziale świętych w zwycięstwach militarnych władców piastowskich pochodzą z okresu od końca X do początków XIII w. Przekaz dotyczący św. Udalryka (w jego przypadku kontekst militarny cudu nie jest całkowicie pewny) powstał poza granicami ziem polskich. Opowieści Brunona i Galla zostały stworzone przez cudzoziemców, którzy jednak ściśle współpracowali z miejscowymi elitami. Treści przekazane w ich pismach najprawdopodobniej stanowiły odzwierciedlenie poglądów władców piastowskich i ich otoczenia, dla których musiały być zrozumiałe. Najpóźniejszy przekaz Kadłubka został już stworzony przez Polaka, który jednak kształcił się na Zachodzie. Omawiane relacje są więc świadectwem przyjmowania kultu świętych i związanych z nim idei przez elitę państwa piastowskiego w ciągłej łączności z myślą zachodnioeuropejską.

W mentalności ludzi średniowiecza cudowne wydarzenia odgrywały niezwykle ważną rolę. Były one widocznym znakiem interwencji Boga w świecie, pełniąc jednocześnie

nie precyzuje, kim był młodzieniec, a więc nie można utożsamiać go z żadnym konkretnym świętym, zob. J. Banaszkiewicz, op. cit., s. 3-9. Tożsamość młodzieńca ma jednak niewielkie znaczenie dla interpretacji dokonanego przez niego cudu.

54 2Mch 10,29-31.

${ }_{55}$ Magistri Vincentii, III 15, s. 101.

56 Ibidem, III 15, s. 101.

57 J. Banaszkiewicz, op. cit., s. 8-16. 
funkcję dydaktyczną, ponieważ każdy z nich niósł przesłanie od Stwórcy ${ }^{5}$. Poprzez cuda Bóg miał uczyć ludzi, jak powinni postępować w codziennym życiu, aby osiągnąć zbawienie ${ }^{59}$. Szczególnie wyraźnie jest to widoczne w przypadku cudownych kar wymierzanych przez świętych np. osobom nie oddającym im należnej czci. Przytoczono wyżej przykład kary, jaką poniósł Otto II za likwidację biskupstwa merseburskiego, równoznaczną ze znieważeniem patrona tej diecezji, św. Wawrzyńca. Cudowne zdarzenia przygotowywały ludzi do pełnienia woli Bożej. Traktowano je jako znaki mające przymnażać wiary lub budzić ją w sercach ludzi ${ }^{60}$. Cudowną pomoc udzieloną przez Boga traktowano jako widomy znak Jego łaski, na którą trzeba było odpowiednio zasłużyć. Ludzie średniowiecza postrzegali cud jako relację wymiany. Wierzono, że niezbędne jest wcześniejsze nawiązanie relacji ze świętym, który, udzielając łaski, odpowiadał na złożoną prośbę, najczęściej połączoną z darem lub pobożnym ślubem. Uważano, że świętego należy bezwzględnie wynagrodzić, aby uniknąć tragicznych niekiedy skutków jego niezadowolenia ${ }^{61}$. Jednak tylko jeden z opisanych cudów - uzdrowienie Mieszka I przez św. Udalryka - poprzedzony był złożeniem wotum. W pozostałych przypadkach święci działają z własnej inicjatywy. Mimo braku bezpośrednich próśb, władcy piastowscy wcześniej nawiązywali kontakt ze swoimi patronami. Bolesław Chrobry wspierał działalność św. Wojciecha i Pięciu Braci jeszcze za ich życia, a po męczeńskiej śmierci otoczył ich ciała należnym kultem. Ten sam władca liczył na pomoc św. Piotra z racji opłacanego trybutu. Św. Wojciech w narracji Galla obronił zagrożony przez Pomorzan gród, odpowiadając na dar w postaci odnowionej katedry, św. Wawrzyniec sprawił cud w dzień swojego święta po tym, jak całe wojsko uczciło tę uroczystość, biorąc udział w nabożeństwie. Młodzieniec opisany przez Kadłubka pojawił się na szczycie kościoła św. Wita, a więc mógł odpowiadać na oddawaną tam świętemu cześć.

Zatem władcy piastowscy, oddając należną cześć świętym spodziewali się w zamian otrzymać ich opiekę. Znakiem ochrony roztoczonej przez Pięciu Braci Męczenników nad okolicą był cudowny blask. Niezwykła światłość towarzyszyła także młodzieńcowi (św. Witowi?) w Kruszwicy ${ }^{62}$. O interwencjach św. Wojciecha, św. Piotra oraz Pięciu Braci świadczył sam fakt odnoszenia zwycięstw przez Bolesława Chrobrego, wierzącego w opiekę świętych. Ich udział w zmaganiach militarnych miał czysto duchowy charakter ${ }^{63}$. Ponadto relikwie św. Wojciecha i Braci spoczywały w jego kraju. Według Galla św. Wojciech sam pojawił się na polu walki. Co więcej, przyszedł on z pomocą księciu w szczególnym dniu - w noc poprzedzającą konsekrację poświęconej mu katedry. Także św. Wawrzyniec interweniował podczas walki z poganami w dniu swojego święta. W przeważającej części przypadków przypisanie zwycięstwa pomocy świętych było więc kwestią interpretacji niezbyt spektakularnych znaków. W przypadku bitwy pod Nakłem piastowska historiografia stara się nawet

\footnotetext{
58 B. Ward, Miracles and the Medieval Mind. Theory, Record and Event 1000-1215, Philadelphia 1982, s. 21.

59 M. Rusecki, Cud w chrześcijaństwie, Lublin 1996, s. 19.

60 Ibidem, s. 32; B. Ward, op. cit., s. 24.

61 P-A. Sigal, op. cit., s. 79-117.

62 O chrześcijańskiej symbolice światła zob.: S. Kobielus, Światło i biel $w$ tradycji wyobrażania chwały eschatologicznej zbawionych (wczesne chrześcijaństwo - średniowiecze), „Communio. Międzynarodowy Przegląd Teologiczny", 11/1991, nr 1, s. 119-135; idem, Źródła światła w średniowiecznej interpretacji, w: idem, Dzieło sztuki - dzieło wiary. Przez widzialne do niewidzialnego, Ząbki 2002, s. 168-179; M. Starnawska, Świętych życie po życiu, s. 443-453.

63 M. Starnawska, Świętych życie po życiu, s. 571.
} 
z biegiem czasu wzmocnić znaczenie udziału sił nadprzyrodzonych w odniesieniu sukcesu militarnego, przedstawiając go jako część Boskiego planu.

Interpretowanie opisanych zwycięstw jako interwencji świętych i podkreślanie ich zasług świadczy o recepcji kultu świętych przez elitę państwa piastowskiego. Ponadto opisy pomocy świętych w bitwach były wykorzystywane już w przypadku Brunona z Kwerfurtu jako argument legitymizujący władzę księcia piastowskiego. Motyw ten rozbudowują Gall Anonim i Wincenty Kadłubek. Świętych uważano za obrońców państwa i starano się podkreślać fakt, że władcy piastowscy w tak ważnym aspekcie sprawowania władzy, jakim były wówczas zmagania militarne, cieszyli się ich wsparciem, tak jak władcy zachodnioeuropejscy, np. Otton I.

Święci wspomagali Piastów w zmaganiach militarnych nie tylko w odpowiedzi na oddawaną im cześć lub wypełniane zobowiązania, ale także w uznaniu ich zasług dla prowadzenia chrystianizacji. Interwencje świętych łączą się bowiem z działalnością misyjną lub walką z poganami. Z tego schematu wyłamuje się jedynie opowieść o uzdrowieniu Mieszka I przez św. Udalryka ze względu na lakoniczność przekazu. Natomiast Bolesław Chrobry wspierał św. Wojciecha i Pięciu Braci Męczenników, a także samego Brunona z Kwerfurtu w ich dziele chrystianizacyjnym. Walki Bolesława Krzywoustego z Pomorzanami pociągnęły za sobą przeprowadzenie przez Ottona z Bambergu misji popieranej przez polskiego księcia. Święci, pomagając władcom piastowskim, nie tylko dbali o ich państwo, ale także w szerszym kontekście troszczyli się o zapewnienie odpowiednich warunków dla ekspansji chrześcijaństwa i nawracania pogan.

Starcia zbrojne zawsze niosły za sobą duże ryzyko, towarzyszyła im niepewność i obawa. Co więcej, władca przegrywający bitwy tracił prestiż zarówno w polityce zagranicznej jak i wśród własnych poddanych. W państwie piastowskim drużyna rycerska utrzymywała się głównie z wojen, podczas których zdobywała łupy i jeńców. Zwycięstwo militarne uważano za dowód uznania władcy przez Boga. Stanowiło ono doskonały argument legitymizujący władzę monarchy, zwłaszcza jeśli zostało odniesione dzięki pomocy sił nadprzyrodzonych. Święci popierali tylko tych władców, którzy wypełniali powierzone im przez Boga obowiązki zgodnie z Jego wolą. Wsparcie patronów, wyrażone w widoczny sposób poprzez cuda, świadczyło o tym, że dany władca cieszył się łaską i uznaniem Niebios. Zapewnienie sobie opieki świętych patronów i przekonanie poddanych o ich wsparciu było więc kluczowe dla zbudowania trwałej wspólnoty politycznej w chrześcijańskiej Europie. Omówione przykłady przekazów o pomocy w walce udzielonej władcom piastowskim świadczą o tym, że panujący z tej dynastii bardzo szybko przyswoili sobie wytworzoną w Europie Zachodniej chrześcijańską ideologię władzy i znaczenie kultu świętych w jej legitymizacji.

\section{The cult of saints and the military victories of the first Piasts (from the 10th to the beginnings of the 13th century) Summary}

The aim of this article is to proceed the analysis of the meaning of saints' and relics' cult in the military victories of the Piasts, from the Ioth to the beginnings of the I3th century. To create a solid political community in Christian Europe it was crucial for a ruler to assure the saints' protection and convince the subjects about their favorable intercession. The stories about the miracles beneficial for the Piasts shows to themselves and to their subjects that the 
rulers were chosen by God, who approves their proceedings. The Piasts became beneficiaries of the miracles due to the proper worshipping of the saints and their relics and in response to their Christianization activity. Using the descriptions of the saints' miraculous support in battles in the texts written for the Piasts as an argument legitimizing and sacralizing their rule is a sign of the early reception and understanding the role of the cult of saints in the ideology of power.

Keywords: The cult of saints, ideology of power, miracles, military actions, Christianization

\section{BIBLIOGRAFIA}

Źródła

Canonici wissegradensis continuatio Cosmae, wyd. H. G. Pertz, „Monumenta Germaniae Historica“", Scriptores in folio (dalej: MGH SS), t. 9, Hannoverae I85I.

Epistola Brunonis ad Henricum regem - List Brunona do króla Henryka, wyd. H. Karwasińska, „Monumenta Poloniae Historica”, series nova (dalej: MPH, s. n.), t. 4, cz. 3, Warszawa 1973, s. 85-I06.

Galli Anonymi cronica et gesta ducum sive principium Polonorum, wyd. K. Maleczyński, MPH, s. n., t. 2, Kraków 1952.

Gerhardi vita Sancti Oudalrici episcopi, wyd. G. Waitz, MGH, SS, t. 4, Hannoverae I84I, s. $377-425$.

Herbordi Dialogus de vita sancti Ottonis episcopi Babenbergensis, wyd. J. Wikarjak, K. Liman, MPH, s. n., t. 7, cz. 3, Warszawa 1974.

Ioannis Dlugossi Annales seu Cronicae incliti Regni Poloniae, red. I Dąbrowski, W. Semkowicz-Zaręba et. al., Warszawa I964.

Kronika Thietmara, wyd. M. Z. Jedlicki, Poznań 1953.

Magistri Vincentii dicit Kadłubek Chronica Polonorum, wyd. M. Plezia, MPH, s. n., t. II, Kraków 1994.

Ottonis episcopi Babenbergensis Vita Prieflingensis, wyd. J. Wikarjak, K. Liman, MPH, s. n., t. 7, cz. I, Warszawa 1966.

Rocznik Małopolski, wyd. A. Bielowski, MPH, t. 3, Lwów I878.

Rocznik Traski, wyd. A. Bielowski, MPH, t. 2, Lwów I872.

Rocznik Krakowski, wyd. A. Bielowski, w: Rocznik Traski, MPH, t. 2, Lwów I872.

Rocznik Sędziwoja, wyd. A. Bielowski, MPH, t. 2, Lwów I872.

Sancti Adalberti Pragensis episcopi et martyris vita altera auctore Brunone Querfurtensi, wyd. J. Karwasińska, MPH, s. n., t. 4, cz. 2, Warszawa 1969.

Vita quinque fratrum eremitarum [seu] vita uel passio Benedictii et Iohannis sociorumque suorum auctore Brunone Querfurtensi, wyd. H. Karwasińska, MPH, s. n., t. 4, cz. 3, Warszawa I973, s. 9-84.

Literatura przedmiotu

Banaszkiewicz J., Włócznia i choragiew. O rycie otwierania bitwy w zwiazku z cudem kampanii nakielskiej Bolesława Krzywoustego (Kadłubek III, I4), „Kwartalnik Historyczny”, 94/1988, z. 4, s. 3-24.

Bozóky E., La politique des reliques de Constantin à Saint Louis, Paris 2006. 
Brown P., Kult świętych: narodziny i rola w chrześcijaństwie łacińskim, tłum. J. Partyka, Kraków 2007.

Derwich M., Kilka uwag w sprawie Pięciu Braci Męczenników, w: Cracovia - Polonia Europa. Studia z dziejów średniowiecza ofiarowane Jerzemu Wyrozumskiemu w sześćdziesiąta piąta rocznice urodzin i czterdziestolecie pracy naukowej, red. K. Baczkowski et al., Kraków i995, s. I8I-I88.

Dunin-Wąsowicz T., Kulty świętych w Polsce w Xw., w: Polska w świecie. Szkice z dziejów kultury polskiej, red. J. Dowiat et al., Warszawa I972, s. 6I-79.

Dunin-Wąsowicz T., Najstarsi polscy święci: Izaak, Mateusz i Krystyn, w: Kościót, kultura, społeczeństwo. Studia z dziejów średniowiecza i czasów nowożytnych, red. S. Bylina, Warszawa 2000, s. 35-47

Dunin-Wąsowicz T., Rzymskie kulty świętych w Polsce wczesnośredniowiecznej: kult św. Maurycego i legionu tebańskiego, „Roczniki Teologiczno-Kanoniczne”, 20/1973, z. 4, S. 25-34.

Geary P., Furta sacra. Thefts of relics in the Central Middle Ages, Princeton 1990.

Górska-Gołaska K., Kult Pięciu Braci Męczenników w Kazimierzu Biskupim, „Roczniki Historyczne", 6I/I995, s. III-I20.

Hermann-Mascard N., Les reliques des saints. Formation coutumière d'un droit, Paris 1975.

Juzepczuk M., Kult relikwii św. Waldeberta $w$ klasztorze $w$ Luxeuil $w$ X wieku w świetle „Miracula sanctorum Waldeberti et Eustasii”, „Średniowiecze polskie i powszechne”, I2/20I6, t. 8, s. I3-45.

Kanonizacja św. Wojciecha i dziedzictwo jego kultu, red. J. Strzelczyk, Cz. Pest, W. Polak, Lublin 200I.

Karwasińska J., Świadek czasów Chrobrego - Brunon z Kwerfurtu, w: Polska w świecie. Szkice z dziejów kultury polskiej, red. J. Dowiat et al., Warszawa I972, s. 9I-I07.

Kobielus S., Światło i biel w tradycji wyobrażania chwały eschatologicznej zbawionych (wczesne chrześcijaństwo - średniowiecze), „Communio. Międzynarodowy Przegląd Teologiczny", II/I99I, nr I, s. II9-I35.

Kobielus S., Źródła światła w średniowiecznej interpretacji, w: idem, Dzieło sztuki-dzieło wiary. Przez widzialne do niewidzialnego, Ząbki 2002, s. I68-I79.

Kürbis B., Dagome iudex. Studium krytyczne, w: Początki państwa polskiego. Ksiega Tysiaclecia, t. 2: Społeczeństwo i kultura, red. K. Tymieniecki, G. Labuda, T. Łowmiański, Poznań i962, s. 363-424.

Kürbis B., Purpurae passionis aureus finis. Bruno z Kwerfurtu i Pięciu Braci Eremitów, w: eadem, Na progach historii, t. 2: O świadectwach do dziejów kultury Polski średniowiecznej, Poznań 200I, s. I63-I80.

Labuda G., Święty Wojciech, biskup-męczennik, patron Polski, Czech i Wegier, Wrocław 2000.

Malicki J., Treści polityczne i ideowe kultu świętych rycerskich w Polsce wcześniejszego średniowiecza. Próba oceny, w: Kultura średniowieczna i staropolska. Studia ofiarowane Aleksandrowi Gieysztorowi w pięćdziesięciolecie pracy naukowej, red. D. Gawinowa et al., Warszawa I99I, s. 387-394.

Michałowski R., Chrystianizacja monarchii piastowskiej, w: Animarum cultura. Studia nad kultura religijna na ziemiach polskich $w$ średniowieczu, t. I: Struktury kościelnopubliczne, Warszawa 2008, s. II-49. 
Michałowski R., Princeps fundator. Studium z dziejów kultury politycznej w Polsce X-XIII wieku, Warszawa 1989.

Michałowski R., Translacja Pięciu Braci Polskich do Gniezna. Przyczynek do dziejów kultu relikwii w Polsce wczesnośredniowiecznej, w: Peregrinationes. Pielgrzymki w kulturze dawnej Europy, red. H. Manikowska, H. Zaremska, Warszawa 1995, s. I73-I84.

Michałowski R., Zjazd gnieźnieński. Religijne przesłanki powstania arcybiskupstwa gnieźnieńskiego, Wrocław 2005.

Paner A., Święty Wit. Męczeństwo, legenda i kult, Gdańsk 1995.

Pauk M. R., Święci patroni a średniowieczne wspólnoty polityczne w Europie Środkowej, w: Sacrum. Obraz i funkcja w społeczeństwie średniowiecznym, red. A. Pieniądz-Skrzypczak, J. Pysiak, Warszawa 2005, s. 237-260.

Pysiak J., Gest władcy $i$ wizualizacja treści ideowych kultu relikwii za panowania Ludwika Świętego, w: Wielkopolska - Polska - Europa. Studia dedykowane pamięci Alicji Karłowskiej-Kamzowej, red. J. Wiesiołowski, J. Kowalski, Poznań 2006, s. I65-I86.

Pysiak J., Król i Korona Cierniowa. Kult relikwii we Francji Kapetyngów, Warszawa 2012.

Pysiak J., Teatralizacja kultu relikwii wśredniowieczu, w: Obrzęd, teatr, ceremoniał w dawnych kulturach, red. J. Olko, Warszawa 2008, s. 3I-44.

Rosik S., Conversio gentis Pomeranorum. Studium świadectwa o wydarzeniu (XII wiek), Wrocław 2010.

Rusecki M., Cud w chrześcijaństwie, Lublin 1996.

Sigal P.-A., L’homme et le miracle dans la France médiévale (XIe-XIIe siècle), Paris 1985.

Soszyński J., Kult św. Wita w Polsce średniowiecznej, „Przegląd Historyczny”, 75/1984, z. 3, s. 463-470.

Starnawska M., Relikwie jako fundament ideowy wspólnoty w tradycji polskich przekazów średniowiecznych ('́sw. św. Wojciech, Florian, Stanisław, Drzewo Krzyża Św. na Łyścu), w: Sacrum. Obraz i funkcja w społeczeństwie średniowiecznym, red. A. Pieniądz-Skrzypczak, J. Pysiak, Warszawa 2005, s. 26I-279.

Starnawska M., Świętych życie po życiu. Relikwie w kulturze religijnej na ziemiach polskich w średniowieczu, Warszawa 2008.

Strzelczyk J., Wandalowie i ich afrykańskie państwo, Warszawa 1992.

Szołdrski W., Spór polsko-czeski o relikwie św. Wojciecha, „Ateneum Kapłańskie”, 42/1950, t. 52, s. $235-265$.

Święty Wojciech w Polskiej tradycji historiograficznej. Antologia tekstów, wyboru dokonał i oprac. G. Labuda, Warszawa 1997.

Trawkowski S., Bolesław Chrobry i eremici, w: Prusy-Polska-Europa. Studia z dziejów średniowiecza i czasów wczesnonowożytnych, red. A. Radzimiński, J. Tandecki, Toruń I999, s. I63-I7I.

Ward B., Miracles and the Medieval Mind. Theory, Record and Event Iooo-I2I5, Philadelphia 1982. 